\title{
THE IMPORTANCE OF MERCURY DETERMINATION AND SPECIATION TO THE HEALTH OF THE GENERAL POPULATION.
}

\author{
PAVLOGEORGATOS G. ${ }^{1, \text { * }}$ \\ KIKILIAS V. ${ }^{2}$
}

\author{
${ }^{1}$ Department of Environmental Studies, \\ University of the Aegean \\ University Hill, Mytilene, Lesvos, GR 81100 \\ 2 "Vostaneio" \\ General Prefectural Hospital of Mytilene \\ Lesvos, GR 81100
}

*to whom all correspondence should be addressed tel: $+30-22510-36613,35,36$

\begin{abstract}
It is well known that the toxicokinetics (i.e. absorption, distribution, metabolism and excretion) of mercury is highly dependent on the form of mercury to which a receptor has been exposed. The aim of this paper is to summarize the available health effects information for mercury and mercury compounds in the international scientific literature (1940-2003) and to point to the need for increased $\mathrm{Hg}$ control of water and food, including mercury speciation, especially in Mediterranean countries.
\end{abstract}

KEYWORDS: Mercury, toxicokinetics, health, speciation, Mediterranean countries.

\section{INTRODUCTION}

The toxicity of mercury is well-known for centuries. The first report pertaining to the toxicity of this metal and its compounds is probably in the works of Plenius Senior (23-79 A.D.) (Huber, 1997). During the Roman Empire, slavery at the Cinnabar mines was used as a terrible punishment for "disobedient" citizens. This was amounting to a slow, painful death (Pavlogeorgatos, 2001).

The first description of industrial poisoning from mercury use is found in 1557 . The workers suffered from chronic exposure to inorganic mercury salt, which resulted in restlessness, depression, lack of concentration and the characteristic hand tremor (Pavlogeorgatos, 2001).
Centuries later in Lewis Caroll's "Alice in wonderland" the existence of mad hatters is mentioned (19 century A.C.), whose insanity was caused by the use of mercury nitrate solutions which were used to the cleaning of felt hats and the processing of beaver pelts which were in fashion at that time for hat-making (Shrader and Hobbins, 1983). This insanity was usually accompanied by a "curious gait", hand tremor, depression, tachycardia, concentration loss etc. The expression "mad as a hatter", was a result of the connection of this particular professional class to the neurological disturbance that is brought by inorganic mercury salt exposure.

In modern history, mass poisonings by mercury 
compounds in many countries (US EPA, 1997b; Forstner - Wittmann, 1983), as for example in Japan on 1950, 1964, 1973 in Iraq on 1972 and in Canada in 1978, lead the scientific community to the intensification of research of the toxic effect of mercury to the living and non-living environment. Despite the fact that mercury is one of the most toxic metals with serious effects on humans and on the environment, its research was seriously delayed, compared to other metals. This could be explained by the following:

Mercury's ability to exist in several physical states and chemical forms at commonly - encountered conditions of temperature and pressure, and its propensity to undergo biological transformations, means that it is subject to complex and difficultto-predict changes in concentration and form. Environmental monitoring studies thus must consider a variety of physical changes, geochemical reactions, and biochemical interactions in an attempt to understand the specific local conditions that contribute to mercury levels found in different environmental media and living things. Mercury is a List I (EEC, 1976) substance and its presence in effluents is controlled by two EEC Directives (EEC, 1982; EEC, 1984).

All scientists who have studied mercury's behaviour, during the last decade, have faced the following problems (Pavlogeorgatos, 2001):

- Mercury has high detection limits in the most widely used analytical techniques used for the determination of heavy metals (AAS, ICPAES).

- Serious contamination problems come up during the sampling, the pre-treatment and the analysis of samples.

- There is a lack of mercury concentrations in some of the existing reference materials.

So, the purposes of this paper are:

1. The survey of the scientific literature (from 1940 to 2003) relating to the effects of different mercury species on the human health.

2. To show the inadequacy of the current European legislation to protect the human health, as much as the environment, from mercury.

3. To indicate the need for increased mercurydetection controls in water and in food especially in the Mediterranean countries. The inhabitants of these countries belong to a high-risk population for exposure to mercury.

\section{SOURCES OF MERCURY IN THE ENVIRONMENT}

The main sources of mercury in the environment are presented in Table 1.

\section{High-risk groups for mercury exposure}

High-risk groups according to their mercury exposure are mainly:

1. Industrial workers (Limbong et al., 2003; Vahter et al., 2002; US EPA, 1997; Piikivini and Hanninen, 1989; Piikivini and Tolonen, 1989; Miller et al., 1975; Barregard et al., 1992; Langolf et al., 1978; Forzi et al., 1978)

2. People living near point sources of mercury emissions (Pavlogeorgatos, 2001; US EPA, 1997).

3. People who consume large amounts of fish (Watanabe et al., 2003; Jewett et al., 2003; Lopez - Alonso et al., 2003; Tsuji and Robinson, 2002; Vahter et al., 2002; Davis et al., 2002; Santos et al., 2002; Sanna et al., 2002; De Santos et al., 2000; Mergler, 2002; Boischio and Henshel, 2000; Airey, 1983).

4. Dental professionals (Sanna et al., 2002; Hol et al., 2001; US EPA, 1997).

5. Chemists and chemical laboratories stuff (Pavlogeorgatos, 2001; Dewhurst, 1974).

In Figure 1 is shown the geographical distribution of Mediterranean mines, which produce the largest quantities of mercury in the world. This fact, together with the fact that Mediterranean inhabitants belong to high-risk groups for mercury exposure 2 and 3 , leads to the conclusion that South Europeans are among the most highly exposed to mercury compounds.

\section{Toxicokinetics of mercury in humans}

Mercury toxicity is caused, mainly, by the fact that it enters the living organism, and reacts with different enzymes inhibiting the catalysis of basic metabolic reactions (WHO, 1990; Public Health Statement, 1990; WHO, 1989; Kouimtzis, 1994). The general population may be exposed to mercury compounds through inhalation of ambient air; consumption of contaminated food, water or soil; and/or dermal exposure to substances containing mercury. In addition, some quantity of mercury is released from dental amalgam.

It is well known that the toxicokinetics (i.e. absorption, distribution, metabolism and excretion) of mercury are highly dependent on the form of mercury to which a receptor has been exposed 
Table 1. Sources of mercury in the environment

(Lopez Alonso et al., 2003; Freed et al., 2002; Sanna et al., 2002; Ansari et al., 1999; US EPA, 1997a and b; Obenauf and Skavroneck, 1997; Huber, 1997; Namasivayam and Periasamy, 1993; Jasinski, 1994; US EPA, 1992b; Lester, 1987; Nurnberg, 1985; WHO, 1989).

\begin{tabular}{|c|c|c|}
\hline \multicolumn{3}{|l|}{ Surface sources of mercury } \\
\hline Burning of oil and its products & Burning of coal & Sanitary landfill \\
\hline Burning of the wastes and sludges & Burning of wood & Geothermic energy \\
\hline Burning of rural by-products & The use of products made by peat & The use of paintings \\
\hline \multicolumn{3}{|l|}{ Point sources of mercury } \\
\hline $\begin{array}{l}\text { Catalyst in the production of } \\
\text { alkaline products }\end{array}$ & Amagalms (Dental work) & Sensors \\
\hline $\begin{array}{l}\text { Manufacturing and using of } \\
\text { explosives }\end{array}$ & Used in batteries & Oscillators \\
\hline $\begin{array}{l}\text { Manufacturing and use of the } \\
\text { fireworks }\end{array}$ & Cleaning solutions & Used in chemical laboratories \\
\hline Use of some preservatives & Relays & Destroyed light bulbs \\
\hline $\begin{array}{l}\text { Used for cosmetics, medicines, } \\
\text { and insecticides }\end{array}$ & Signal transmitters & Coverings of different paper forms \\
\hline $\begin{array}{l}\text { Medicines for poultry and farm } \\
\text { animals }\end{array}$ & Rectifiers & \\
\hline \multicolumn{3}{|l|}{ Industrial sources of mercury } \\
\hline $\begin{array}{l}\text { Sodium carbonate and chloride } \\
\text { production units }\end{array}$ & $\begin{array}{l}\text { Cinnabar }(\mathrm{HgS}) \\
\text { production units }\end{array}$ & $\begin{array}{l}\text { Pulp and paper } \\
\text { production units }\end{array}$ \\
\hline $\begin{array}{l}\text { Photographic equipment and } \\
\text { consumables production units }\end{array}$ & $\begin{array}{l}\text { Gold or silver mining and } \\
\text { processing units }\end{array}$ & $\begin{array}{l}\text { Electric and electronic appliance } \\
\text { production units }\end{array}$ \\
\hline $\begin{array}{l}\text { Lead, copper and zinc mining and } \\
\text { processing units }\end{array}$ & $\begin{array}{l}\text { Plant chemicals } \\
\text { production units }\end{array}$ & $\begin{array}{l}\text { Cement } \\
\text { production units }\end{array}$ \\
\hline $\begin{array}{l}\text { Units of secondary mercury } \\
\text { production }\end{array}$ & Coal side products & Coal production units \\
\hline Instrument production units & Fluorescent bulb recycling plants & Color paint production units \\
\hline Light bulb production units & Furnaces & Battery production units \\
\hline Explosives production units & Refineries & \\
\hline
\end{tabular}

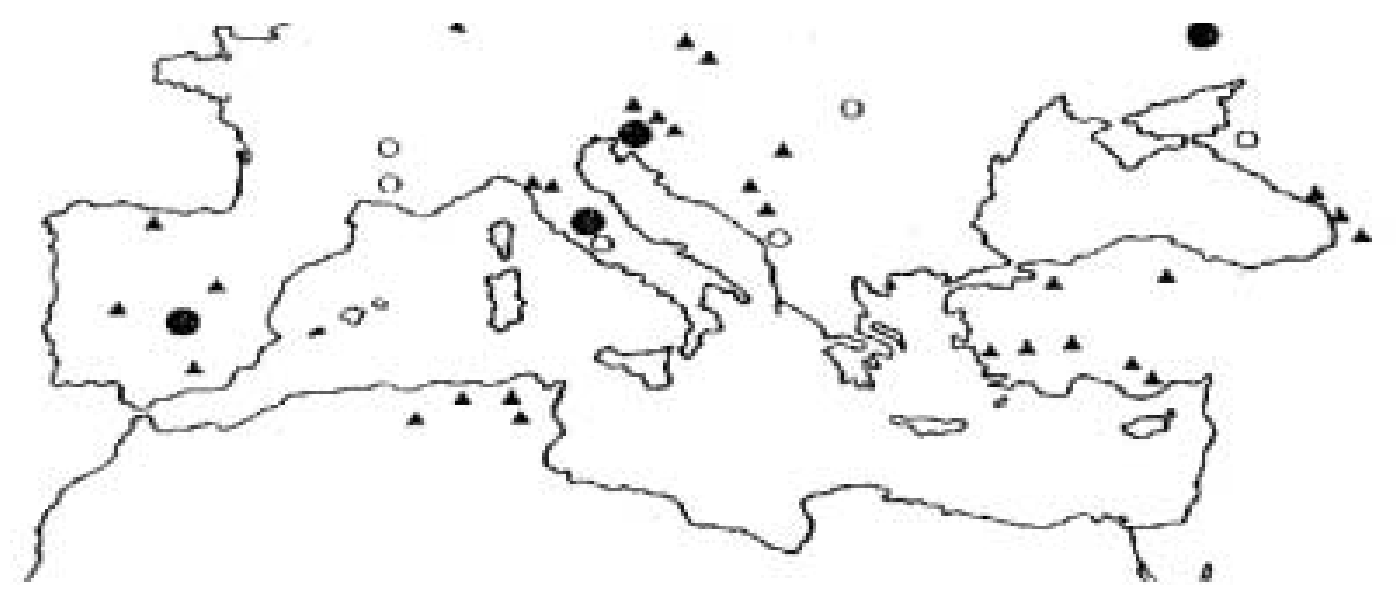

Figure 1. Geographical distribution of mercury mines in the Mediterranean. (UNEP, 1987)

( Highly productive mines, $\bigcirc$ increased concentrations of mercury, $\boldsymbol{\Delta}$ formerly productive mines). 
Table 2. Absorption and adsorption of different forms of mercury by the human body

\begin{tabular}{|c|c|c|}
\hline Mercury form & $\begin{array}{l}\text { Ways of absorption by the human } \\
\text { organism }\end{array}$ & References \\
\hline Elemental Hg & $\begin{array}{l}\text { The respiratory absorption of elemen- } \\
\text { tal mercury is the major way of absorp- } \\
\text { tion in humans ( }>75-85 \% \text { of the total } \\
\text { uptake). Through the lungs it is eventu- } \\
\text { ally transported to the bloodstream. } \\
\text { Gastrointestinal tract absorption is neg- } \\
\text { ligible }(0.01 \%) \text {. }\end{array}$ & $\begin{array}{l}\text { Loredo et al., 2003; DeRouen et al., } \\
\text { 2002; Finkelman et al., 2002; Nielsen - } \\
\text { Kudsk, 1965; Oikawa et al., 1982; } \\
\text { Teisinger and Fiserova-Bergova, 1965; } \\
\text { Hursh, 1985; Hursh et al., 1985; Levine } \\
\text { et al., 1982; Berlin et al., 1969; } \\
\text { Bornmann et al., 1970; Berlin, 1986; } \\
\text { US EPA, 1997c. }\end{array}$ \\
\hline $\begin{array}{l}\text { Inorganic } \mathrm{Hg} \\
\text { compounds }\end{array}$ & $\begin{array}{l}\text { The degree of absorption of inorganic } \\
\text { mercury by the gastrointestinal tract } \\
\text { varies, and depends on which mercuric } \\
\text { salt is involved in this process ( } 7-15 \%) \text {. } \\
\text { Absorption diminishes with the } \\
\text { decrease in solubility. Estimates on the } \\
\text { degree of uptake of inorganic mercury } \\
\text { vary, though it is greater than } 20 \% \text { of } \\
\text { the total Hg uptake. In general, biva- } \\
\text { lent Hg, because it has a greater solu- } \\
\text { bility than the univalent, is more } \\
\text { absorbed and more toxic. There is no } \\
\text { data about dermal absorption. }\end{array}$ & $\begin{array}{l}\text { Loredo et al., 2003; Clarkson, 1989; } \\
\text { Miettinen, 1973; Rahola et al., 1973; } \\
\text { Foulkes and Bergman, 1993; US EPA, } \\
\text { 1997c; Endo } \text { et al., 1990; Sin } \text { et al., } 1983 .\end{array}$ \\
\hline $\begin{array}{l}\text { Alkyl mercury } \\
\text { compounds }\end{array}$ & $\begin{array}{l}\text { Methyl-mercury is rapidly and in a } \\
\text { large degree absorbable ( } 95 \% \text { ) by the } \\
\text { gastrointestinal system. Information } \\
\text { pertaining to the inspiratory absorption } \\
\text { of this compound is limited. The per- } \\
\text { centage of dermal absorption is } \\
\text { unknown ( } 3-5 \% \text { in laboratory animals). }\end{array}$ & $\begin{array}{l}\text { Loredo et al., 2003; Iyengar and Rapp, } \\
\text { 2001; Fang, 1980; US EPA, 1997c; } \\
\text { Dunn } \text { et al., 1981; Aberg et al., 1969; } \\
\text { Miettinen, 1973; Kershaw et al., 1980; } \\
\text { Miettinen } \text { et al., 1971; Sherlock et al., } \\
\text { 1982; Skog and Wahlberg, 1964. }\end{array}$ \\
\hline $\begin{array}{l}\text { Other organic } \mathrm{Hg} \\
\text { compounds. }\end{array}$ & $\begin{array}{l}\text { There is a small amount of absorption } \\
\text { by the respiratory and dermal system, } \\
\text { and complete absorption by the gas- } \\
\text { trointestinal system (this is true for } \\
\text { acetic phenyl-mercury and less so for } \\
\text { methoxy-ethyl-mercury). }\end{array}$ & $\begin{array}{l}\text { US EPA, 1997c; Stratis and } \\
\text { Zachariades, 1989; Pavlogeorgatos, } \\
2001 .\end{array}$ \\
\hline
\end{tabular}

(US EPA, 1997). As a result we must approach differently the toxicokinetics of each form of mercury in the human organism according to:

- Absorption (Table 2)

- Excretion (Table 3)

- Distribution (Table 4)

- Biological action (Table 5)

- Affected organs (Table 6)

- Detoxification and suppression (Table 7), and
- Borderline concentrations of different $\mathrm{Hg}$ forms in the human body (Table 8).

On Table 9 the latest data on hazard identification and dose-response assessment are summarized, according to the U.S. EPA.

Finally on Table 10 the effects of mercury compounds on human health are summarized according to the international scientific literature (from 1940 to 2003). 
Table 3. Excretion of different forms of mercury by the human body

\begin{tabular}{|c|c|c|}
\hline Form of mercury & $\begin{array}{l}\text { Ways of excretion from the human } \\
\text { body }\end{array}$ & References \\
\hline Elemental $\mathrm{Hg}$ & $\begin{array}{l}\text { Elemental } \mathrm{Hg} \text { is excreted from the } \\
\text { human body in the urine, feces, expired } \\
\text { air, sweat and saliva. Variations of the } \\
\text { form of excretion depend on the } \\
\text { degree of oxidation of elemental Hg to } \\
\text { mercuric mercury. In general, a low- } \\
\text { level exposure is related to a, mainly, } \\
\text { fecal excretion, while a high-level expo- } \\
\text { sure is related to a mainly urinary. }\end{array}$ & $\begin{array}{l}\text { Roels et al., 1991; Stopford et al., 1978; } \\
\text { Hursh et al., 1976; Cherian et al., 1978; } \\
\text { Magos, 1973; Roels et al., 1987; Roels } \\
\text { et al., 1985; Lovejoy et al., 1974; } \\
\text { Rothstein and Hayes, 1964; US EPA, } \\
\text { 1997c; Stratis and Zachariades, } 1989 .\end{array}$ \\
\hline $\begin{array}{l}\text { Inorganic } \mathrm{Hg} \\
\text { compounds }\end{array}$ & $\begin{array}{l}\text { On a low-level exposure, it is excreted } \\
\text { mainly by the stool (approximately } \\
85 \% \text { ), while on a high-level exposure } \\
\text { mainly by the urine (approximately } \\
35 \% \text { ). }\end{array}$ & $\begin{array}{l}\text { Miettinen, 1973; Rahola et al., 1973; } \\
\text { Rothstein and Hayes, 1964; Berlin, } \\
\text { 1986; Cherian } \text { et al., 1978; Ballatori and } \\
\text { Clarkson, 1982; Yoshida et al., 1992; } \\
\text { US EPA, 1997c; Stratis and } \\
\text { Zachariades, 1989. }\end{array}$ \\
\hline Alkyl Hg. & $\begin{array}{l}\text { Its clearance from the human organism } \\
\text { is accomplished by excretion in stool, } \\
\text { maternal milk and urine. }\end{array}$ & $\begin{array}{l}\text { Myers G.J. et al., 2000; Vahter et al., } \\
\text { 2000; Drexler and Schaller, 1998; Aberg } \\
\text { et al., 1969; Bernard and Purdue, 1984; } \\
\text { Miettinen, 1973; Smith et al., 1970; } \\
\text { Norseth and Clarkson, 1971; Clarkson, } \\
\text { 1993; Rowland } \text { et al., 1980; Stratis and } \\
\text { Zachariades, 1989; Farris et al., 1993; } \\
\text { Hollins et al., 1975; Thomas et al., 1987; } \\
\text { Bakir et al., 1973; Sundberg and } \\
\text { Oskarson, 1992; Greenwood et al., } \\
\text { 1978; Skerfving, 1988. }\end{array}$ \\
\hline $\begin{array}{l}\text { Other organic } \mathrm{Hg} \\
\text { compounds. }\end{array}$ & It is the same as the inorganic mercury. & $\begin{array}{l}\text { US EPA, 1997c; Stratis and } \\
\text { Zachariades, 1989; Pavlogeorgatos, } \\
2001 .\end{array}$ \\
\hline
\end{tabular}

\section{CONCLUSIONS}

As Tables 1-10 indicate the main conclusions of this report are:

1. Mercury causes serious damages to the human organism, mainly of a neurological nature, which can even lead to the death of the exposed individual. The severity of these damages depends on the quantity acquired, the duration of the exposure and the chemical species of mercury.

2. The inhabitants of the Mediterranean basin belong to the high-risk groups for exposure to different forms of mercury, because of their dietary habits and their proximity to natural mercury sources.

3. The current European legislation sets the maximum allowed limits for total mercury concentration in drinkable water and in food (mainly of sea origin), but does not demand the chemical speciation of the detected mercury. Also, it should be mentioned, that in many Mediterranean countries the food and water control for mercury detection is negligent and occasional, because mercury detection demands additional equipment, specialized staff and meticulous care in sampling and analysis. 
Table 4. Allocation of different forms of mercury in the human body

\begin{tabular}{|c|c|c|}
\hline Forms of mercury & Allocation in the human organism & References \\
\hline Elemental $\mathrm{Hg}$ & $\begin{array}{l}\text { It is mainly transported by red blood } \\
\text { cells ( }>98 \% \text { of the total uptake) and } \\
\text { accumulates mainly on the cerebral } \\
\text { gray matter (especially the fetal during } \\
\text { pregnancy). }\end{array}$ & $\begin{array}{l}\text { US EPA, 1997c; Hursh et al., 1988; } \\
\text { Hursh et al., 1985; Hursh et al., 1976; } \\
\text { Nordberg and Serenius, 1969; } \\
\text { Rothstein and Hayes, 1964; Takahata et } \\
\text { al., } 1970 .\end{array}$ \\
\hline $\begin{array}{l}\text { Inorganic } \mathrm{Hg} \\
\text { compounds }\end{array}$ & $\begin{array}{l}\text { It is allocated by bloodstream to the } \\
\text { whole human organism and accumu- } \\
\text { lates mainly in liver and kidneys. }\end{array}$ & $\begin{array}{l}\text { Vahter et al., 2002; Hac et al., 2000; } \\
\text { Newton and Fry, 1978; Rothstein and } \\
\text { Hayes, 1960; Cember, 1962; Piotrowski et } \\
\text { al., 1975; US EPA, 1997c; Piotrowski et } \\
\text { al., 1973; Stratis and Zachariades, } 1989 .\end{array}$ \\
\hline Alkyl Hg & $\begin{array}{l}\text { Circulates unchanged in the blood- } \\
\text { stream for long periods of time. A per- } \\
\text { centage of the total (about } 10 \% \text { ) accu- } \\
\text { mulates in the brain and the placenta } \\
\text { of pregnant women. Also in spleen, } \\
\text { heart and hair. }\end{array}$ & $\begin{array}{l}\text { Ehrenstein et al., 2002; Vahter et al., } \\
\text { 2002; Hac et al., 2000; Iyengar and } \\
\text { Rapp, 2001; Clarkson, 1972; Hansen, } \\
\text { 1988; Hansen } \text { et al., 1989; Nielsen } \text { et al., } \\
\text { 1994; Soria et al., 1992; Suzuki et al., } \\
\text { 1984; US EPA, 1997c. }\end{array}$ \\
\hline Other organic $\mathrm{Hg}$ & $\begin{array}{l}\text { Because of their dissociation to biva- } \\
\text { lent } \mathrm{Hg} \text { in the liver, it is the same as } \\
\text { the inorganic mercury. }\end{array}$ & US EPA, 1997c; Pavlogeorgatos, 2001. \\
\hline
\end{tabular}

Table 5. Biological action of different forms of mercury in the human body

\begin{tabular}{|c|c|c|}
\hline Forms of mercury & Biological action & References \\
\hline Elemental $\mathrm{Hg}$ & $\begin{array}{l}\text { It easily enters tissue and red blood } \\
\text { cells where is oxidized to bivalent mer- } \\
\text { cury, with the help of a catalase. }\end{array}$ & $\begin{array}{l}\text { Halbach and Clarkson, 1978; US EPA, } \\
\text { 1997c; Stratis and Zachariades, } 1989 .\end{array}$ \\
\hline $\begin{array}{l}\text { Inorganic } \mathrm{Hg} \\
\text { compounds }\end{array}$ & $\begin{array}{l}\text { Because of its increased chemical rela- } \\
\text { tion to the SH- groups, found on pro- } \\
\text { tein molecules, it inhibits enzyme } \\
\text { action. It has an effect on the metabo- } \\
\text { lism of amino acids in the brain and } \\
\text { blocks the functions of cell membrane, } \\
\text { because of its chemical relation to the } \\
\mathrm{PO}^{4} \text {-groups. But, there are also reports } \\
\text { of a reduction of inorganic mercury } \\
\text { compounds to the elemental form of } \\
\text { this metal. }\end{array}$ & $\begin{array}{l}\text { Dunn et al., 1981; Clarkson and } \\
\text { Rohstein, 1964; Sugata and Clarkson, } \\
\text { 1979; US EPA, 1997c. }\end{array}$ \\
\hline Alkyl Hg & $\begin{array}{l}\text { Using red blood cells it penetrates the } \\
\text { blood-brain barrier, and inhibits the } \\
\text { enzyme action of glycolysis and the } \\
\text { protein synthesis mechanisms. }\end{array}$ & $\begin{array}{l}\text { Ehrenstein et al., 2002; US EPA, 1997c; } \\
\text { Pavlogeorgatos, } 2001\end{array}$ \\
\hline $\begin{array}{l}\text { Other organic } \mathrm{Hg} \\
\text { compounds }\end{array}$ & $\begin{array}{l}\text { It dissociates in the liver to produce } \\
\text { bivalent and benzol. Accordingly, it has } \\
\text { the same action as inorganic mercury. }\end{array}$ & $\begin{array}{l}\text { US EPA, 1997c; Stratis and } \\
\text { Zachariades, 1989; Pavlogeorgatos, } \\
2001 .\end{array}$ \\
\hline
\end{tabular}


Table 6. Critical organs of the human body in its exposure to different forms of mercury.

\begin{tabular}{|lll|}
\hline Form of mercury & Critical organs & References \\
\hline Elemental Hg & $\begin{array}{l}\text { In a brief, high-level exposure, } \\
\text { the lungs. In a long-term exposure } \\
\text { the Central Nervous System (CNS) } \\
\text { and especially the brain. }\end{array}$ & $\begin{array}{l}\text { Karimi } \text { et al., 2002; Adams } \text { et al., 1983; } \\
\text { Founds } \text { et al., 1987; McFarland and } \\
\text { Reigel, 1978; Snodgrass } \text { et al., 1981; } \\
\text { Sexton } \text { et al., 1978; Vroom and Greer, } \\
\text { 1972; US EPA, 1997c; Stratis and } \\
\text { Zachariades, 1989. }\end{array}$ \\
$\begin{array}{lll}\text { Inorganic } \mathrm{Hg} \\
\text { compounds }\end{array}$ & Mainly the kidneys. & $\begin{array}{l}\text { Vahter } \text { et al., 2002; Carrier } \text { et al., 2001 } \\
\text { (a and b); US EPA, 1997c; } \\
\text { Pavlogeorgatos, 2001; Stratis and } \\
\text { Zachariades, 1989. }\end{array}$ \\
\hline $\begin{array}{l}\text { Alkyl Hg } \\
\text { Brain and CNS. }\end{array}$ & $\begin{array}{l}\text { Ehrenstein } \text { et al., 2002; Iyengar and Rapp, } \\
\text { 2001; US EPA, 1997c; Pavlogeorgatos, } \\
\text { 2001; Stratis and Zachariades, 1989. }\end{array}$ \\
\hline $\begin{array}{l}\text { Other organic } \mathrm{Hg} \\
\text { compounds }\end{array}$ & $\begin{array}{l}\text { In case of a chronic exposure the kid- } \\
\text { neys and probably the liver. }\end{array}$ & $\begin{array}{l}\text { US EPA, 1997c; Stratis and Zachariades, } \\
1989 ; \text { Pavlogeorgatos, 2001. }\end{array}$ \\
\hline
\end{tabular}

Table 7. Detoxification and action suppression of different forms of mercury in the human body.

\begin{tabular}{|c|c|c|}
\hline Mercury form & Detoxifying compounds & References \\
\hline Elemental $\mathrm{Hg}$ & $\begin{array}{l}\text { Vitamin } \mathrm{E} \text { is reported to be a protective } \\
\text { agent. Additionally, ethanol reduces the } \\
\text { human organism ability for absorption of } \\
\text { elemental mercury, possibly by suppress- } \\
\text { ing the activity of the catalase, which oxi- } \\
\text { dizes it to produce bivalent } \mathrm{Hg} \text {. Tellurium } \\
\text { also appears to have a protective role. }\end{array}$ & $\begin{array}{l}\text { Dunn et al., 1981; Nielsen - Kudsk, } \\
\text { 1965; US EPA, 1997c; Stratis and } \\
\text { Zachariades, 1989; Magos and Webb, } \\
\text { 1979; Khayat and Dencker, 1982, 1984a } \\
\text { and b. }\end{array}$ \\
\hline $\begin{array}{l}\text { Inorganic } \mathrm{Hg} \\
\text { compounds }\end{array}$ & $\begin{array}{l}\text { Metaltheionin has a protective role. } \\
\text { Also various mercury-chelating com- } \\
\text { pounds (e.g. bimercapto-propanol), } \\
\text { accelerate its excretion. Finally, it is } \\
\text { worth mentioning that selenium seems } \\
\text { to have a protective action by binding } \\
\mathrm{Hg} \text { to HgSe and limiting its acute } \\
\text { action on intestine and kidneys. } \\
\text { Tellurium also has a protective role. }\end{array}$ & $\begin{array}{l}\text { Hol et al., 2001; Magos and Webb, } \\
\text { 1979; US EPA, 1997c; Khayat and } \\
\text { Dencker, 1984a; Zalups and Cherian, } \\
\text { 1992; Stratis and Zachariades, } 1989 .\end{array}$ \\
\hline Alkyl Hg & $\begin{array}{l}\text { Evidence from other mammals indicates } \\
\text { that selenium has a protective role } \\
\text { against organic mercury also. It is } \\
\text { reported, without impressive clinical } \\
\text { results, that the N-acetyl product of D, } \\
\text { L penicilamine accelerates its excretion. } \\
\text { Also vitamin E reduces the toxicity and } \\
\text { increases survival chances after an expo- } \\
\text { sure to methyl-mercury. }\end{array}$ & $\begin{array}{l}\text { Hol et al., 2001; Myers et al., 2000; } \\
\text { Grandjean, 1992; Ballatori and } \\
\text { Clarkson, 1982; Welsh, 1979; US EPA, } \\
\text { 1997c. }\end{array}$ \\
\hline $\begin{array}{l}\text { Other organic } \mathrm{Hg} \\
\text { compounds }\end{array}$ & $\begin{array}{l}\text { Glutathion probably catalyzes the rapid } \\
\text { dissociation of the } \mathrm{Hg}-\mathrm{C} \text { bond. }\end{array}$ & $\begin{array}{l}\text { US EPA, 1997c; Fukino et al., 1992; } \\
\text { Girardi and Elias, } 1991 .\end{array}$ \\
\hline
\end{tabular}


Table 8. Borderline concentrations of different forms of mercury in the human body

\begin{tabular}{|c|c|c|}
\hline Mercury form & Borderline concentration & References \\
\hline Elemental Hg & 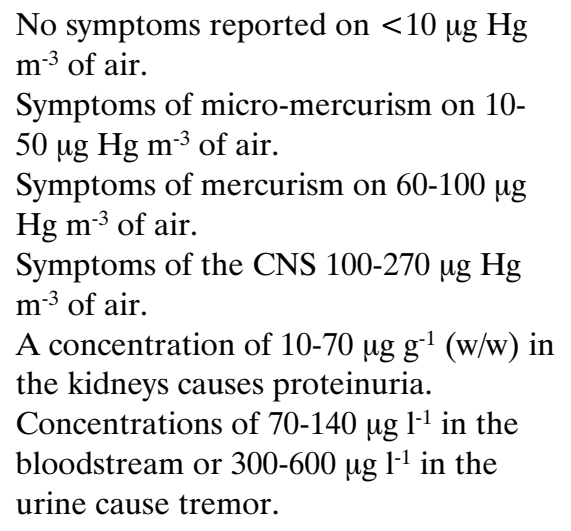 & $\begin{array}{l}\text { US EPA, 1997c; Stratis and } \\
\text { Zachariades, 1989; Pavlogeorgatos, } \\
\text { 2001; Roels et al., 1982; Verbeck et al., } \\
\text { 1986. }\end{array}$ \\
\hline $\begin{array}{l}\text { Inorganic } \mathrm{Hg} \\
\text { compounds }\end{array}$ & $\begin{array}{l}\text { Micro-mercurism from } 10-50 \mu \mathrm{g} \mathrm{Hg} \mathrm{m}^{-3} \\
\text { of air. } \\
\text { Chronic mercurism }>100 \mu \mathrm{g} \mathrm{Hg} \mathrm{m}^{-3} \text { of } \\
\text { air. } \\
\text { Concentrations from } 10-40 \mu \mathrm{gg} \mathrm{g}^{-1} \text { of } \\
\text { renal tissue cause temporary damage, } \\
\text { while in }>100 \mu \mathrm{g} \mathrm{Hg} \mathrm{g} \mathrm{g}^{-1} \text { causes serious } \\
\text { kidney damage }\end{array}$ & $\begin{array}{l}\text { US EPA, 1997c; Stratis and } \\
\text { Zachariades, 1989; Pavlogeorgatos, } \\
2001 .\end{array}$ \\
\hline Alkyl Hg & $\begin{array}{l}\text { 1.2-3.4 } \mu \mathrm{g} \mathrm{MeHg} \mathrm{l}^{-1} \text { in the brain cause } \\
\text { the first symptoms. } \\
\text { Concentrations of } 6-17 \mu \mathrm{g} \mathrm{MeHg} \mathrm{l^{-1 }} \text { in } \\
\text { brain are fatal. } \\
\text { Lethal doses for liver respectively are } \\
>10 \mu \mathrm{g} \mathrm{MeHg} \mathrm{g}^{-1} \text { and for blood }>3000 \\
\mathrm{ng} \mathrm{MeHg} \mathrm{\textrm {g } ^ { - 1 } .} \text { In general, on levels high- } \\
\text { er than } 25 \mathrm{mg} / 70 \mathrm{~kg} \text { of body weight sense } \\
\text { disturbances are caused, over } 90 \mathrm{mg} \\
\text { dysarthria and over } 170 \mathrm{mg} \text { deafness. }\end{array}$ & $\begin{array}{l}\text { US EPA, 1997c; Stratis and } \\
\text { Zachariades, 1989; Pavlogeorgatos, } \\
2001 .\end{array}$ \\
\hline $\begin{array}{l}\text { Other organic } \mathrm{Hg} \\
\text { compounds }\end{array}$ & $\begin{array}{l}\text { A concentration of } 6 \mathrm{mg} \mathrm{l}^{-1} \text { in the urine } \\
\text { causes the appearance of albuminuria. } \\
\text { Ingestion of a quantity }<1250 \mathrm{mg} \text { of } \\
\text { salt causes very mild gastrointestinal } \\
\text { disturbances. On levels of between } 0.2 \\
\text { and } 5.1 \mathrm{mg} \mathrm{m}^{-3} \text { of atmospheric air no } \\
\text { symptoms were reported. }\end{array}$ & $\begin{array}{l}\text { US EPA, 1997c; Stratis and } \\
\text { Zachariades, 1989; Pavlogeorgatos, } \\
2001 .\end{array}$ \\
\hline
\end{tabular}


Table 9. Summary of U.S. EPA Hazard Identification /Dose-response Assessment for mercury and Mercury compounds (US EPA, 1997c).

\begin{tabular}{|c|c|c|c|}
\hline $\begin{array}{l}\text { Form of mercury } \\
\text { Parameter }\end{array}$ & Elemental Hg & Inorganic $\mathbf{H g}$ & Organic $\mathbf{H g}$ \\
\hline $\begin{array}{l}\text { Oral RfD A } \\
\text { (mg kg-1-day) }\end{array}$ & $\mathrm{n} / \mathrm{a}^{\mathrm{A}}$ & 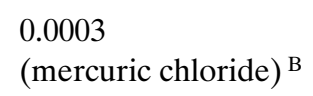 & $\begin{array}{l}0.0001 \\
(\mathrm{MeHg})^{\mathrm{E}}\end{array}$ \\
\hline $\begin{array}{l}\text { Inhalation RfC } \\
\left(\mathrm{mg} \mathrm{m}^{-3}\right)\end{array}$ & $0.0003^{\text {в }}$ & Not verifiable ${ }^{\mathrm{D}}$ & $\mathrm{n} / \mathrm{a}$ \\
\hline $\begin{array}{l}\text { Cancer Weight -of - } \\
\text { evidence Rating }\end{array}$ & $\begin{array}{l}\mathrm{D}, \text { not classifiable as to } \\
\text { human carcinogenicity } \mathrm{F}\end{array}$ & $\begin{array}{l}\text { C, possible human } \\
\text { carcinogen } \mathrm{F}\end{array}$ & $\begin{array}{l}\mathrm{C} \text {, possible human } \\
\text { carcinogen } \mathrm{F}\end{array}$ \\
\hline Cancer Slope Factor & $\mathrm{n} / \mathrm{a}$ & $\mathrm{n} / \mathrm{a}$ & $\mathrm{n} / \mathrm{a}$ \\
\hline $\begin{array}{l}\text { Germ Cell } \\
\text { Mutagenicity }\end{array}$ & $\begin{array}{l}\text { Low weight of } \\
\text { evidence }\end{array}$ & $\begin{array}{l}\text { Moderate weight of } \\
\text { evidence }\end{array}$ & $\begin{array}{l}\text { High weight of } \\
\text { evidence }\end{array}$ \\
\hline $\begin{array}{l}\text { Developmental } \\
\text { Toxicity Data Base } \\
\text { Characterization }\end{array}$ & $\begin{array}{l}\text { Insufficient human } \\
\text { evidence; sufficient } \\
\text { animal evidence }\end{array}$ & $\begin{array}{l}\text { Insufficient } \\
\text { evidence }\end{array}$ & $\begin{array}{l}\text { Sufficient human and } \\
\text { animal data }\end{array}$ \\
\hline \multicolumn{4}{|c|}{$\begin{array}{l}\text { A: Not available; data do not support development of a value at this time. } \\
\text { B: Critical effect is neurological toxicity (hand tremor; increases in memory disturbances; slight subjective } \\
\text { and objective evidence of autoimmune dysfunction) in adults. } \\
\text { C: Critical effects is renal toxicity resulting from an autoimmune disease caused by the accumulation of a } \\
\text { hapten - mercury complex in the glomerular region of the kidneys. } \\
\text { D: Data were judged insufficient for calculation of RfC. } \\
\text { E: Critical effect is neurological toxicity in progeny of exposed women, RfD calculated using a benchmark } \\
\text { dose ( } 10 \% \text { ). } \\
\text { F: US EPA categorizes all chemical compounds into five categories according to their connection to } \\
\text { carcinogenesis. Ranging from A (proven carcinogenic compounds) to E (proven non-carcinogenic } \\
\text { compounds). }\end{array}$} \\
\hline
\end{tabular}


Table 10. Effects of mercury compounds on human health.

\begin{tabular}{|c|c|}
\hline Effect & References which support it \\
\hline Aneuploidy & Renzoni et al., 1998; Verschaeve et al., 1976. \\
\hline $\begin{array}{l}\text { Autoimmune } \\
\text { diseases (S.L.E., } \\
\text { Scleroderma, } \\
\text { Glomerulonephritis) }\end{array}$ & Hess, 2002; Lawrence and MacCabe, 2002; Sondreal et al., 2002. \\
\hline Birth of a dead fetus & Vahter et al., 2002; Sikorski et al., 1987 \\
\hline $\begin{array}{l}\text { Blindness - Visual } \\
\text { disturbances }\end{array}$ & $\begin{array}{l}\text { Finkelman et al., 2002; Mergler, 2002; Altmann et al., 1998; Snyder and Seelinger } \\
\text { 1976; Amin - Zaki et al., } 1974 .\end{array}$ \\
\hline $\begin{array}{l}\text { Characteristic hand } \\
\text { tremor }\end{array}$ & $\begin{array}{l}\text { DeRouen et al., 2002; Harada et al., 2001; Drasch et al., 2001;Harada et al., 1999; } \\
\text { Kang-Yum and Oransky, 1992; Roels et al., 1982; Verbeck et al.,1986; Harada, } \\
\text { 1978; Derobert and Tara, 1950. }\end{array}$ \\
\hline $\begin{array}{l}\text { Chromosomal } \\
\text { abnormalities }\end{array}$ & Santos et al., 2002; Renzoni et al., 1998; Popescu et al., 1979. \\
\hline Coma & Cinca et al., 1979. \\
\hline $\begin{array}{l}\text { Congenital } \\
\text { malformations }\end{array}$ & Vahter et al., 2002; Myers et al., 2000; Sikorski et al., 1987. \\
\hline Death & $\begin{array}{l}\text { Mergler, 2002; Myers et al., 2000; Mitsumori et al., 1990; Tamashiro et al., 1984; } \\
\text { Bakir et al., 1973; Mitsumori et al., 1981; Troen et al., } 1951 .\end{array}$ \\
\hline $\begin{array}{l}\text { Delay in speech and } \\
\text { in walking and mental } \\
\text { retardation of new- } \\
\text { borns }\end{array}$ & $\begin{array}{l}\text { Vahter et al., 2002; Mergler, 2002; Redwood et al., 2001; Myers et al., 2000; } \\
\text { Futatsuka et al., 2000; Sondreal et al., 2000; Marsh et al., 1987; Harada, } 1978 .\end{array}$ \\
\hline Depression & Mergler, 2002; DeRouen et al., 2002; US EPA, 1997c. \\
\hline $\begin{array}{l}\text { Difficulty in } \\
\text { speech }\end{array}$ & $\begin{array}{l}\text { DeRouen } \text { et al., 2002; Futatsuka et al., 2000; Bakir et al., 1980; Cinca et al., 1979; } \\
\text { Harada, 1978; Bakir } \text { et al., } 1973 .\end{array}$ \\
\hline $\begin{array}{l}\text { Dyspnoia- } \\
\text { Pneumonitis }\end{array}$ & DeRouen et al., 2002; Bluhm et al., 1992; Snodgrass et al., 1981; Hallee, 1969. \\
\hline Fetal miscarriage & Karimi et al., 2002; Cordier et al., 1991; Afonso and DeAlvarez, 1960. \\
\hline $\begin{array}{l}\text { Growth retardation } \\
\text { in exposed children }\end{array}$ & Akagi et al., 2000. \\
\hline Hallucinations & Marsh et al., 1987; Bakir et al., 1980; Bakir et al., 1973; Harada, 1978. \\
\hline $\begin{array}{l}\text { Hypertension, } \\
\text { tachycardia }\end{array}$ & Soni et al., 1992; Fagala and Wigg, 1992; Snodgrass et al., 1981; Hook et al., 1954. \\
\hline $\begin{array}{l}\text { Immune system } \\
\text { suppression }\end{array}$ & Mattingly et al., 2001; Sondreal et al., 2000 \\
\hline
\end{tabular}




\begin{tabular}{|c|c|}
\hline Effect & References which support it \\
\hline $\begin{array}{l}\text { Increased incidence } \\
\text { of leukemia } \\
\text { (in methyl-mercury } \\
\text { exposure) })^{1}\end{array}$ & Santos et al., 2002; Janicki et al., 1987. \\
\hline $\begin{array}{l}\text { Increased incidence } \\
\text { of liver cancer } \\
\text { (in methyl-mercury } \\
\text { exposure) })^{1}\end{array}$ & Tamashiro et al., 1986. \\
\hline Insanity & Davis et al., 1974. \\
\hline $\begin{array}{l}\text { Lack of cooperation } \\
\text { abilities. }\end{array}$ & Derobert and Tara, 1950. \\
\hline $\begin{array}{l}\text { Loss of } \\
\text { concentration }\end{array}$ & $\begin{array}{l}\text { Mergler, 2002; DeRouen et al., 2002; Redwood et al., 2001; Clarkson et al., 1976; } \\
\text { Nordberg and Strangert, 1976; WHO, } 1976 .\end{array}$ \\
\hline Loss of hearing & Mergler 2002; Harada et al., 2001; Amin-Zaki et al., 1974. \\
\hline Loss of memory & DeRouen et al., 2002; Redwood et al., 2001; Drasch et al., 2001; US EPA, 1997c. \\
\hline $\begin{array}{l}\text { Loss of the touch } \\
\text { sensation }\end{array}$ & Harada et al., 2001; Mergler, 2002; Harada et al., 1999; Hook et al., 1954. \\
\hline Lung cancer & $\begin{array}{l}\text { Amandus and Costello, 1991; Barregard et al., 1990; Buiatti et al., 1985; Ellingsen et } \\
\text { al., } 1992 .\end{array}$ \\
\hline Male subfertility & Dickman and Leung, 1998. \\
\hline $\begin{array}{l}\text { Minamata syndrome: } \\
\text { motor disturbance, } \\
\text { seizures, retardation, } \\
\text { palsy in the } \\
\text { developing fetus }\end{array}$ & Sondreal et al., 2000. \\
\hline Muscular weakness & Harada et al., 2001; Kang-Yum and Oransky, 1992; McKeown-Eyssen et al., 1983 \\
\hline $\begin{array}{l}\text { Nausea, vomiting up to } \\
\text { severe gastroenteritis }\end{array}$ & Harada et al., 2001; Afonso and DeAlvarez, 1960; Troen et al., 1951. \\
\hline Paralysis & Harada et al., 2001; US EPA, 1997c. \\
\hline Pneumonia & Hallee, 1969. \\
\hline Restlessness & US EPA, 1997c. \\
\hline $\begin{array}{l}\text { Up to } 55 \% \text { reduction } \\
\text { on human brain } \\
\text { weight and volume }\end{array}$ & Clarkson et al., 1976; Nordberg and Strangert, 1976; WHO, 1976. \\
\hline $\begin{array}{l}\text { Walking deficits - } \\
\text { Ataxia }\end{array}$ & $\begin{array}{l}\text { Futatsuka et al., 2000; Myers et al., 2000; Cinca et al., 1979; Von Burg and Rustam, } \\
1974 \text { a and b; Hunter et al., } 1940 .\end{array}$ \\
\hline
\end{tabular}

${ }^{1}$ No available data about the carcinogenic abilities of inorganic mercury in humans (US EPA, 1997c) 


\section{REFERENCES}

Aberg, B., Ekman, R., Falk, U., Greitz, G., Persson, I. and Snihs, J. (1969), Metabolism of methyl mercury $\left({ }^{203} \mathrm{Hg}\right)$ compounds in man: Excretion and distribution, Arch. Environ. Health, 19, 478-484.

Adams, C., Ziegler, D. and Lin, J. (1983), Mercury intoxication simulating amyotrophic lateral sclerosis, J. Am. Med. Assoc., 250, 642-643.

Afonso, J. and DeAlvarez, R. (1960), Effects of mercury on human gestation, Am. J. Obstet. Gynecol., 80, 145-154. Airey, D. (1983), Mercury in hair due to environment and diet: a review, Environ. Helath Perspect., 52, 303-316.

Akagi, H., Castillo, E.S., Cortes-Maramba, N., Francisco-Rivera, A.T. and Timbang, T.D. (2000), Health assessment for mercury exposure among schoolchildren residing near a gold processing and refining plant in Apokon, Tagum, Davao del Norte, Philippines, The Science of the Total Environment, 259, 31-43.

Altmann, L., Sveinsson, K., Kramer, U., Weishoff-Houben, M., Turfeld, M., Winneke, G. and Wiegand, H. (1998), Visual Functions in 6-Year-Old Children in Relation to Lead and Mercury Levels, Neurotoxicology and Teratology, 20, 9-17.

Amandus, H. and Costello, J. (1991), Silicosis and lung cancer in U.S. metal miners, Arch. Environ. Health, 46, 82-89.

Amin-Zaki, L., Elhassani, S. and Majeed, M.A. (1974), Intra-uterine methyl mercury poisoning in Iraq, Pediatrics, 84, 587-595.

Ansari, M.H., Deshkar, A.M., Kelkar, P.S., Dharmadhikari, D.M., Hasan, M.Z. and Paramasivam, R. (1999), Mercury removal from Wastewater by Streamed Hoof Powder, Wat. Sci. Tech., 40, 109-116.

Bakir, F., Damluji, S.F. and Amin-Zaki, L. (1973), Methyl mercury poisoning in Iraq, Science, 181, 230-241.

Bakir, F., Rustam, H., Tikriti, S., Al-Damluji, S.F. and Shihristani, H. (1980), Clinical and epidemiological aspects of methyl mercury poisoning, Postgrad. Med. J., 56, 1-10.

Ballatori, N. and Clarkson, T. (1982), Development changes in the biliary excretion of methyl mercury and glutathione, Science, 216, 61-63.

Barregard, L., Sallsten, G., Schutz, A., Attewell, R., Skerfving, S. and Jarvholm, B. (1992), Kinetics of mercury in blood and urine after brief occupational exposure, Arch. Environ. Health, 47, 176-184.

Barregard, L., Sallsten, G. and Jarvholm, B. (1990), Mortality and cancer incidence in chlor-alkali workers exposed to inorganic mercury, Br. J. Ind. Med., 47, 99-104.

Berlin, M. (1986), Mercury. In: Handbook on the toxicology of Metals, $2^{\text {nd }}$ ed., Friberg, L., Nordberg, G.R., Vouk, V.B., Ed. Elsevier Press, New York, N.Y.

Berlin, M., Nordberg, G. and Serenius, F. (1969), On the site and mechanism of mercury vapor resorption in the lung, Arch. Environ. Health, 18, 42-50.

Bernard, S. and Purdue, P. (1984), Metabolic models for methyl and inorganic mercury, Health Phys., 46, 695-699.

Bluhm, R.E., Bobbitt, R.G., Welch, L.W., Wood, A.J.J., Bonfiglio, J.F., Sarzen, C., Heath, A.J. and Branch, R.A. (1992), Elemental mercury vapor toxicity, treatment, and prognosis after acute, intensive exposure in Chlor-alkali plant workers: Part I. History, neuropsychological findings and chelator effects. Hum. Exp. Toxicol., 11, 201-210.

Boischio, A.A.P. and Henshel, D. (2000), Fish Consumption, Fish Lore, and Mercury Pollution - Risk Communication for the Madeira River People, Environmental Research Section A, 84, 108-126.

Bornmann, G., Henke, G., Alfes, H., Molman, H. (1970), Concerning the entaral absorption of metallic mercury, Arch. Toxicol., 26, 203-209.

Brune, D., Nordberg, G.R., Vesterberg, O., Gerhardsson, L. and Wester, P.O. (1991), A review of normal concentration of mercury in human blood, Sci. Total Environ., 100, 235-282.

Buiatti, E., Kriebel, D. and Geddes, M. (1985), A case control study of lung cancer in Florence, Italy: I. Occupational risk factors, J. Epidemiol. Comm. Health., 39, 244-250.

Carrier, G., Brunet, R.C., Caza, M. and Bouchard, M. (2001a, b), A Toxicokinetic Model for Predicting the Tissue Distribution and Elimination of Organic and Inorganic Mercury Following Exposure to Methyl Mercury in Animals and Humans. I. Development and Validation of the Model Using Experimental Data in Rats, Toxicology and Applied Pharmacology, 171, 38-49.

Cember, H. (1962), The influence of the size of the dose on the distribution and elimination of inorganic mercury, $\mathrm{Hg}\left(\mathrm{NO}_{3}\right)_{2}$ in the rat, Am. Ind. Health. Assoc. J., 23, 304-313.

Cherian, M.G., Hursh, J.G. and Clarkson, T.W. (1978), Radioactive mercury distribution in biological fluids and excretion in human subjects after inhalation of mercury vapor, Arch. Environ. Health, 33, 190-114. 
Cinca, I., Dumitrescu, I. and Opaca, P. (1979), Accidental ethyl - mercury poisoning with nervous system, skeletal muscle and myocardium injury, J. Neurol. Neurosurg. Psychiat., 43, 143-149.

Clarkson, T.W. (1972), The Pharmacology of mercury compounds, Ann. Rev. Pharmacol., 12, 375-406.

Clarkson, T.W. (1989), Mercury., J. Am. Coll. Toxicol., 8, 1291-1296.

Clarkson, T.W. and Rohstein, A. (1964), The excretion of volatile mercury by rats injected with mercuric salts, Health Phys., 10, 1115-1121.

Clarkson, T.W. (1993), Molecular and ionic mimicry of toxic metals, Annu. Rev. Pharmacol. Toxicol., 32, 545-571.

Clarkson, T.W., Amin-Zaki, L. and Al-Tikriti, S. (1976), An outbreak of methyl mercury poisoning due to consumption of contaminated grain, Fed. Proc., 35, 2395-2399.

Cordier, S., Deplan, F., Mandereau, L. and Hemon, D. (1991), Paternal exposure to mercury and spontaneous abortions, Br. J. Ind. Med., 48, 375-381.

Davis, J.A., May, M.D., Greenfield, B.K., Fairey, R., Roberts, C., Ichikawa, G., Stoelting, M.S., Becker, J.S. and Tjeerdema, R.S. (2002), Contaminant concentrations in sport fish from San Francisco Bay, 1997, Marine Pollution Bulletin, 44, 1117-1129.

Davis, L.E., Wands, J.R., Weiss, S.A., Price, D.L. and Girling, E.F (1974), Central nervous system intoxication from mercurous chloride laxatives-quantitative, histochemical and ultra structure studies, Arch. Neurol., 30, 428-431.

Derobert, L. and Tara, S. (1950), Mercury intoxication in pregnant women, Ann. Med. Leg., 30, 222-225.

DeRouen, T.A., Leroux, B.G., Martin, M.D., Townes, B.D., Woods, J.S., Leitão, J., Castro-Caldas, A. and Braveman, N. (2002), Issues in design and analysis of a randomized clinical trial to assess the safety of dental amalgam restorations in children, Controlled Clinical Trials, 23, 301-320.

Dewhurst, F. (1974), Laboratory safety, Laboratory news, 76, 18-19.

Dickman, M.D. and Leung, K.M.C. (1998), Mercury and organochlorine exposure from fish consumption in Hong Kong, Chemosphere, 37, 991-1015.

Dos Santos, L. do S.N., Muller, R.C.S., Sarkis, J.E. de S., Alvesa, C.N., Braboc, E. da S., Santos, E. de O. and Bentes, M.H. da S. (2000), Evaluation of total mercury concentrations in fish consumed in the municipality of Itaituba, Tapajos River Basin, Para, Brazil, The Science of the Total Environment, 261, 1-8.

Drasch G., Bose-O'Reilly, S., Beinhoff, C., Roider, G. and Maydl, S. (2001), The Mt. Diwata study on the Philippines 1999 - assessing mercury intoxication of the population by small scale gold mining, The Science of the Total Environment, 267, 151-168.

Drexler, H. and Schaller, K.-H. (1998), The Mercury Concentration in Breast Milk Resulting from Amalgam Fillings and Dietary Habits, Environmental Research, Section A, 77, 124-129.

Dunn, J.D., Clarkson, T.W. and Magos, L. (1981), Ethanol reveals nevel mercury detoxification step in tissues, Science, 213, 1123-1125.

EEC (1976), Council Directive on pollution caused by certain dangerous substances discharged into the aquatic environment of the community, (76/464), Off. J. Eur. Community, L129 (18-5-1976), p. 23.

EEC (1982), Council Directive on limit values and quality objectives for mercury discharges by the chlor-alkali electrolysis industry, (82/176), Off. J. Eur. Community, L81 (27-3-82), p. 29.

EEC (1984), Council Directive on limit values and quality objectives for mercury discharges by sectors other than the chlor-alkali electrolysis industry, (84/156), Off. J. Eur. Community, L74 (17-3-1984), p. 49.

Ehrenstein, C., Shu, P., Wickenheiser, E.B. and Hirner, A.V. (2002), Methyl mercury uptake and associations with the induction of chromosomal aberrations in Chinese hamster ovary (CHO) cells, Chemico-Biological Interactions, 141, 259-274.

Ellingsen, D., Andersen, A., Nordhagen, H.P., Efskind, J. and Kjuus, H. (1992), Cancer incidence and mortality among workers exposed to mercury in the Norwegian chloralkali industry, In: $8^{\text {th }}$ International Symposium on Epidemiology in Occupational Health, Paris, France, September 10-12, 1991 Rev. Epidemiol. Sante Publique, 40 (suppl. 1), S93-S94.

Endo, T., Nakaya, S. and Kimura, R. (1990), Mechanisms of absorption of inorganic mercury from rat small intestine: III Comparative absorption studies of inorganic mercuric compounds in vivo, Pharmacol. Toxicol., 66, 347-353.

Fagala, G.E. and Wigg, C.L. (1992), Psychiatric manifestations of mercury poisoning, J. Am. Acad. Child. Adolesc. Psyciat, 31, 306-311.

Fang, S.C. (1980), Comparative study of uptake and tissue distribution of methyl mercury in female rats by inhalation and oral routes of administration, Bull. Environ. Contam. Toxivol., 24, 65-72. 
Farris, F.F., Dedrick, R.L., Allen, P.V. and Smith, J.C. (1993), Physiological model for the pharmacokinetics of methyl mercury in the growing rat, Toxicol. Appl. Pharmacol., 119, 74-90.

Finkelman, R.B., Orema, W., Castranova, V., Tatu, C.A., Belkin, H.E., Zheng, B., Lerch, H.E., Maharaj, S.V. and Bates, A.L. (2002), Health impacts of coal and coal use: possible solutions, International Journal of Coal Geology, 50, 425 - 443.

Forstner - Wittmann (1983), Metal Pollution in the Aquatic Environment, Second Revised Edition, SprongerVerlag, New York.

Forzi, M., Cassitto, M. G., Bulgheroni, C. and Foa, V. (1978), Psychological measures in workers occupationally exposed to mercury vapours: A validation study, In: Adverse effects on environmental chemicals and phychotropic drugs: Neurophysiological and behaviour tests, Vol 2, Zimmerman, H.J., Ed. Appleton Century -Crofts, New York, NY, pp. 165-171.

Foulkes, E.C. and Bergman, D. (1993), Inorganic mercury absorption in mature and immature rat jejunum: Transcellular and intercellular pathways in vivo and in everted sacs, Toxicol. Appl. Pharmacol., 120, 89-95.

Founds, D., Copeland, K. and Franks, R. (1987), Mercury poisoning and acrodynia. Am. J. Dis. Child., 141, 124125.

Freed, G.L., Andreae, M.C., Cowan, A.E. and Katz, S.L. (2002), Vaccine safety policy analysis in three European countries: the case of thimerosal, Health Policy, 62, 291-307.

Fukino, H., Hirai, M. and Ideura, K. (1992), Effect of the administration of mercuric chloride on zinc deficiency in rats, J. Food. Hyg. Soc. Jpn., 33, 31-38.

Futatsuka, M., Kitano, T., Shono, M., Fukuda, Y., Ushijima, K., Inaoka, T., Nagano, M., Wakamiya, J. and Miyamoto, K. (2000), Health Surveillance in the Population Living in a Methyl Mercury-Polluted Area over a Long Period, Environmental Research Section A, 83, 83-92.

Girardi, G. and Elias, M. M. (1991), Effectiveness of n-acetylcysteine in protecting against mercuric chlorideinduced nephrotoxicity, Toxicology, 67, 155-164.

Grandjean, P., Weihe, P., Jorgensen, P.J., Clarkson, T., Cernichiari, E. and Videro, T. (1992), Impact of maternal seafood diet on fetal exposure to mercury selenium and lead, Arch. Environ. Health, 47, 185-195.

Greenwood, M.R., Clarkson, T.W., Doherty, R.A., Gates, A.H, Amin-Zaki, L., Elhassani, S. and Majeed, M.A. (1978), Blood clearance half-times in lactating and nonlactating members of a population exposed to methyl mercury, Environ. Res., 16, 48-54.

Hac, E., Krzyzanowski, M. and Krechniak, J. (2000), Total mercury in human renal cortex, liver, cerebellum and hair, The Science of the Total Environment, 248, 37-43.

Halbach, S. and Clarkson, T.W. (1978), Enzymic oxidation of mercury vapor by erytrocytes, Biochem. Biophys. Acta., 523, 522-531.

Hallee, T.J. (1969), Diffuse lung disease caused by inhalation of mercury vapor, Am. Rev. Respir. Dis., 99, 430-436.

Hansen, J. (1988), Blood mercury concentrations in birthgiving Greenlandic women, Artic. Med. Res., 41, 175-178.

Hansen, J., Reske-Nielsen, E., Thorlacius-Ussing, O., Rungby, J. and Danscher, G. (1989), Distribution of dietary mercury in a dog. Quantitation and localization of total mercury in organs and central nervous system. Sci. Total Environ., 78, 23-43.

Harada, H. (1978), Congenital Minamata disease: Intrauterine methyl mercury poisoning, Teratology, 18, 285-288.

Harada, M., Nakanishi, J., Yasoda, E., da Conceicao, M., Pinheiro, N., Oikawa, T., Guimaraes, G. de Assis, Cardoso, B. da silva, Kizaki, T. and Ohno, H. (2001), Mercury pollution in the Tapajos River basin, Amazon Mercury level of head hair and health effects, Environment International, 27, 285-290.

Harada, M., Nakachi, S., Tasaka, K., Sakashita, S., Muta, K., Yanagida, K., Doi, R., Kizaki, T. and Ohno, H. (2001), Wide use of skin-lightening soap may cause mercury poisoning in Kenya, The Science of the Total Environment, 269, 183-187.

Harada, M., Nakachi, S., Cheu, T., Hamada, H., Ono, Y., Tsuda, T., Yanagida, K., Kizaki, T. and Ohno, H. (1999), Monitoring of mercury pollution in Tanzania: relation between head hair mercury and health, The Science of the Total Environment, 227, 249-256.

Hess, E.V. (2002), Environmental chemicals and autoimmune disease: cause and effect, Toxicology, 181-182, 65-70.

Hol, P.J., Vamnes, J.S., Gjerdet, N.R., Eide, R. and Isrenn, R. (2001), Dental Amalgam and Selenium in Blood, Environmental Research, Section A, 87, 141-146.

Hollins, J., Willes, R., Bryce, F., Charbonneau, S.M. and Munro, I.C. (1975), The whole body retention and tissue distribution of $\left[{ }^{203} \mathrm{Hg}\right]$ methyl mercury in adult cats, Toxicol. Appl. Pharmacol., 33, 438-449. 
Hook, O., Lundgren, K.-D. and Swensson, A. (1954), On alkyl mercury poisoning, Acta. Med. Scand., 150, 131137.

Huber, K. (1997), The Wisconsin Mercury SourceBook, US EPA Pollution Prevention Incentives for States Grant \#NP985072-01-1, Wisconsin Department of Natural Resources Bureau of Watershed Management (WT/2), P.O. Box 7921, Madison, Wisconsin 53707-7921 (608) 267-7694.

Hunter, D., Bomford, R.R. and Russell, D.S. (1940), Poisoning by methyl mercury compounds, Quart. J. Med.I, 9, 193-213.

Hursh, J.B. (1985), Partition coefficients of Mercury $\left({ }^{203} \mathrm{Hg}\right)$ vapor between air and biological fluids. 1985, J. Appl. Toxicol., 5, 327-332.

Hursh, J.B., Sichak, S.P. and Clarkson, T.W. (1988), In vitro oxidation of mercury by the blood, Pharmacol. Toxicol., 63, 266-273.

Hursh, J.B., Clarkson, T.W., Cherian, M.G., Vostal, J.J. and Mallie, P.V. (1976), Clearance of mercury (Hg-197, Hg-203) vapor inhaled by human subjects, Arch. Environ. Health, 31, 302-309.

Hursh, J.B., Clarkson, T.W., Nowak, T.V., Pabico, R.C., Mckenna, B.A., Miles, E. and Gibb, F.R. (1985), Prediction of kidney mercury content by isotope techniques, Kidney Int., 27, 898-907

Iyengar, G.V. and Rapp, A. (2001), Human placenta as a "dual" biomarker for monitoring fetal and maternal environment with special reference to potentially toxic trace elements. Part 3: Toxic trace elements in placenta and placenta as a biomarker for these elements, The Science of the Total Environment, 280, 221-238.

Janicki, K., Dobrowolski, J. and Drasnicki, K. (1987), Correlation between contamination of the rural environment with mercury and occurrence of leukemia in men and cattle, Chemosphere, 16, 253-257.

Jasinski, S.M. (1994), The material flow of mercury in the United States, U.S. Dep. of the Interior, Burreau of Mines Information Circular 9412.

Jewett, S.C., Zhang, X., Naidu, A.S., Kelley, J.J., Dasher, D. and Duffy, L.K. (2003), Comparison of mercury and methylmercury in northern pike and Arctic grayling from western Alaska rivers, Chemosphere, 50, 383-392.

Kang-Yum, E. and Oransky, S.H. (1992), Chinese patient medicine as a potential source of mercury poisoning, Vet. Hum. Toxicol., 34, 235-238.

Karimi, A., Moniri, F., Nasihatkon, A., Zarepoor, M.J. and Alborzi, A. (2002), Mercury Exposure Among Residents of a Building Block in Shiraz, Iran, Environmental Research Section A, 88, 41-43.

Kershaw, T.G., Clarkson, T.W. and Dhahir, P.H. (1980), The relationship between blood levels and dose of methylmercury in man, Arch. Environ. Health, 35, 28-36.

Khayat, A. and Dencker, L. (1982), Fetal uptake and distribution of metallic mercury vapor in the mouse: Influence of ethanol and aminotriazole, Int. J. Biol. Res. Pregnancy, 38-46.

Khayat, A. and Dencker, L. (1984a), Interactions between tellurium and mercury in murine lung and other organs after metallic mercury inhalation: A comparison with selenium. Chem. Biol. Interact., 50, 123-133.

Khayat, A. and Dencker, L. (1984b), Organ and cellular distribution of inhaled metallic mercury in the rat and Marmoset monkey. (Callithrix jacchus): Influence of ethyl alcohol pre-treatment, Acta. Pharmacol. Toxicol., 55, 145-152.

Kouimtzis, Th. (1994), Environmental Chemistry, Ziti Publishers, Thessalonica, Greece (in greek).

Langolf, G.D., Chaffin, D.B., Henderson, R. and Whittle, H.P. (1978), Evaluation of workers exposed to elemental mercury using quantitative tests. Am. Ind. Hyg. Assoc. J., 39, 976-984.

Lawrence, D.A. and McCabe, M.J.Jr. (2002), Review: Immunomodulation by metals, International Immunopharmacology, 2, 293- 302.

Lester, N.J. (1987), Heavy Metals in Wastewater and Sludge Treatment Processes - Volume I, eds. Stephenson, T., London, England.

Levive, S.P., Cavender, G.D., Langolf, G.D. and Albers, J.W. (1982), Elemental mercury exposure: Peripheral neurotoxicit, Br. J. Ind. Med., 39, 136-139.

Limbong, D., Kumampung, J., Rimper, J., Arai, T. and Miyazaki, N. (2003), Emissions and environmental implications of mercury from artisanal gold mining in north Sulawesi, Indonesia, The Science of the Total Environment, 302, 227-236.

Lopez Alonso, M., Benedito, J.L., Miranda, M., Castillo, C., Hernandez, J. and Shore, R.F. (2003), Mercury concentrations in cattle from NW Spain, The Science of the Total Environment, 302, 93-100.

Loredo, J., Pereira, A. and Ordonez, A. (2003), Untreated abandoned mercury mining works in a scenic area of Asturias (Spain), Environmental Int., 1043, 1-11. 
Lovejoy, H.B., Bell, Z.G. and Vizena, T.R. (1974), Mercury exposure evaluations and their correlation with urine mercury excretion, J. Occup. Med., 15, 590-591.

Magos, L. and Webb, M. (1979), Synergism and antagonism in the toxicology of mercury. In: The biogeochemistry of mercury in the environment, Nriagu, J.O., Ed. Elsevier/ North Holland Biomedical Press, New York, NY, pp. 581-599.

Magos, L. (1973), Factors affecting the uptake and retention of mercury by kidneys in rats, In: Mercury, Mercurials and Mercaptans, Miller, M.W. and Clarkson, T.W., Ed. CC Thomas, Springfield, IL, pp. 67-186.

Marsh, D.O., Clarkson, T.W., Cox, C., Amin-Zaki, L. and Al-Tikriti, S. (1987), Fetal methyl mercury poisoning: Relathionship between concentration in single strands of maternal hair and child effects, Arch. Neurol., 44, 1017-1022.

Mattingly, R.R., Felczak, A., Chen, C-C., McCabe, M.J. Jr. and Rosenspire, A.J. (2001), Low Concentrations of Inorganic Mercury Inhibit Ras Activation during T Cell Receptor-Mediated Signal Transduction, Toxicology and Applied Pharmacology, 176, 162-168.

McFarland, R. and Reigel, H. (1978), Chronic mercury poisoning from a single brief exposure, J. Occup. Med., 20, 534-534.

McKeown-Eyssen, G.E., Ruedy, J. and Neims, A. (1983), Methyl mercury exposure in Northern Quebec: II. Neurologic findings in children, Am. J. Epidemiol., 118, 470-479.

Mergler, D. (2002), Review of neurobehavioral deficits and river fish consumption from the Tapajos (Brazil) and St. Lawrence (Canada), Environmental Toxicology and Pharmacology, 12, 93-99.

Miettinen, J.K. (1973), Absorption and elimination of dietary $\left(\mathrm{Hg}^{++}\right)$and methyl mercury in man. In: Mercury, Mercurial, and Mercaptans, Miller, M.W. and Clarkson, T.W., Ed. Springfield, IL, pp. 233-243.

Miettinen, J.K., Rahola, T., Hattula, T., Rissanen, K. and Tillander, M. (1971), Elimination of 203 - Hgmethylmercury in man, Ann. Clin. Res., 3, 116-122.

Miller, J., Chaffin, D. and Smith, R. (1975), Subclinical psychomotor and neuromuscular changes in workers exposed to inorganic mercury, Am. Ind. Hyg. Assoc. J., 36, 725-733.

Mitsumori, K., Hirano, M., Ueda, H., Maita, K. and Shirasu, Y. (1990), Chronic toxicity and carcinogenicity of methyl mercury chloride in B6C3F1 mice, Fund Appl. Toxicol., 14, 179-190.

Mitsumori, K., Maita, K. and Saito, T. (1981), Carcinogenicity of methyl mercury chloride in IRC mice: Preliminary note on renal carcinogenesis, Cancer Lett., 12, 305-310.

Myers, G.J., Davidson, P.W., Cox, C., Shamlaye, C., Cernichiari, E. and Clarkson, T.W. (2000), Twenty-Seven Years Studying the Human Neurotoxicity of Methylmercury Exposure, Environmental Research Section $A, \mathbf{8 3}, 275-285$.

Namasivayam, C. and Periasamy, K. (1993), Bicarbonate-treated peanut hull carbon for mercury (II) removal from aqueous solution, Water Res., 27, 1663-1668.

Newton, D. and Fry, F. (1978), The retention and distribution of radioactive mercuric oxide following accidental inhalation, Ann. Occup. Hy. 21, 21-32.

Nielsen, J.B., Andersen, O. and Grandjean, P. (1994), Evaluation of mercury in hair, blood and muscles as biomarkers for methyl-mercury exposure in male and female mices, Arch. Toxicol., 68, 317-321.

Nielsen-Kudsk, F. (1965), The influence of ethyl alcohol on the absorption of methyl mercury vapor from the lungs of man, Acta Pharmacol. Toxicol., 23, 263-274.

Nordberg, G and Serenius, F. (1969), Distribution of inorganic mercury in the guinea pig brain, Acta. Pharmacol. Toxicol., 27, 269-283

Nordberg, G.F. and Strangert, P. (1976), Estimations of a dose-response curve for long-term exposure to methylmercuric compounds in human being taking into account availability of critical organ concentration and biological halt time: A preliminary communication, In: Effects and Dose-Response Relationships of Toxic Metals, Nordberg, G.F., Ed. Elsevier, Amsterdam. pp. 73-282.

Norseth, T and Clarkson, T.W. (1971), Intestinal transport of $\mathrm{Hg}$ - 203- labelled methyl mercury chloride: Role of biotransfrormation in rats, Arch. Environ. Health., 22, 568-577

Nurnberg, H. (1985), Pollutants and Their Ecotoxicological Significance, John Wiley and Sons Ltd.

Obenauf, P. and Skavroneck, S. (1997), Mercury Source Sector Assessment for the Greater Milwaukee Area, Pollution Prevention Partnership and the Milwaukee Metropolitan Sewerage District, Milwaukee, USA.

Oikawa, K., Saito, H., Kufene, I., Ohshina, T., Fujii, M. and Takizawa, Y. (1982), Mercury absorption by inhaling through the nose and expiring through the mouth at various concentrations, Chemosphere, 11, 943-951. 
Pavlogeorgatos, G. (2001), The fate of mercury in an activated sludge pilot plant, PhD thesis, Department of Environmental Studies, University of the Aegean, Lesvos, Greece (in greek).

Piikivini, L. and Hanninen, H. (1989), Subjective symptoms and psychological performance of chlor-alkali workers. Scand, J. Work Environ. Health., 15, 69-74.

Piikivini, L. and Tolonen, U. (1989b), EEG findings in chlor-alkali workers subjected to low long-term exposure to mercury vapour. Br., J. Ind. Med., 46, 370-375.

Piotrowski, J., Trojanowska, B. and Mogilnicka, E.M. (1975), Excretion kinetics and variability of urinary mercury in workers exposed to mercury vapor, Int. Arch. Occup. Environ. Health, 35, 245-256.

Piotrowski, J., Trojanowska, B. and Wisneiwska-Knypl, J. (1973), Further investigations on binding and release of mercury in the rat, In: Mercury, Mercurials and Mercaptans, Miller, M. and Clarkson, T., Ed. Springfield, IL, pp. 247-263.

Popescu, H.I., Negru, L., and Lancranjan (1979), Chromosome aberrations induced by occupational exposure to mercury, Arch. Environ. Health, 34, 461-463.

Public Health Statement (1990), Mercury, USA.

Rahola, T., Hattula, T., Korolainen, A. and Miettinen, J.K. (1973), Elimination of free and protein bound ionic mercury in man, Ann. Clin. Res., 5, 214-219.

Redwood, L., Bernard, S. and Brown, D. (2001), Predicted mercury concentrations in hair from infant immunizations: Cause for concern, Neurotoxicology, 22, 691-697.

Renzoni, A., Zino, F. and Franchi, E. (1998), Mercury Levels along the Food Chain and Risk for Exposed Populations, Environmental Research, Section A, 77, 68-72.

Roels, H., Lauwerys, Gennart, J.P., Buchet, J.P., Malchaire, J. and Bernard, A. (1985), Surveillance of workers exposed to mercury vapour: Validation of previously proposed biological threshold limit value for mercury concentration in urine, Am. J. Ind. Med., 7, 45-71.

Roels, H., Abdeledim, S., Ceulemans, E. and Lauwerys, R. (1987), Relationships between the concentrations of mercury in air and in blood or urine in workers expsed to mercury vapor, Ind. Occup. Hyg., 31, 135-145.

Roels, H.A., Boeckyx, M., Ceulemans, E. and Lauwerys, R. (1991), Urinary excretion of mercury after occupational exposure to mercury vapor and influence of the chelating agent meso-2,3-dimercaptosuccinic acid (DMSA), Br. J. Ind. Med., 48, 247-253.

Roels, H.A., Lauwerys, R. and Buchet, J.P. (1982), Comparison of rnal function and psychomotor performance in workers exposed, Int. Arch. Occup. Environ. Health, 50, 77-93.

Rohstein, A. and Hayes, A.L. (1960), The metabolism of mercury in the rat studied by isotope techniques. L. Pharmacol, Exp. Ther., 130, 166-176.

Rothstein, A. and Hayes, A.L. (1964), The turnover of mercury in rats exposed repeatedly to inhalation of vapor, Health. Phys., 10, 1099-1113.

Rowland, I., Davies, M. and Evans, J. (1980), Tissue content of mercury in rats given methyl mercury chloride orally: Influence of intestinal flora, Arch. Environ. Health., 35, 155-160.

Sanna, G., Pilo, M.I., Piu, P.C., Spano, N., Tapparo, A., Campus, G.G. and Seeber, R. (2002), Study of the shortterm release of the ionic fraction of heavy metals from dental amalgam into synthetic saliva, using anodic stripping voltammetry with microelectrodes, Talanta, 58, 979-985.

Santos, E.C.O., de Jesús, I.M., Brabo, E. da Silva, Brito Loureiro, E.C., Mascareñas, A.F. da Silva, Weirich, J., Camara, V.M. and Cleary, D. (2000), Mercury Exposures in Riverside Amazon Communities in Para, Brazil, Environmental Research Section A, 84, 100-107.

Santos, E. C.O., Camara, V.M., Jesus, I.M., Brabo, E.S., Loureiro, E.C.B., Mascarenhas, A.F.S., Fayal, K.F., SaH Filho, G.C., Sagica, F.E.S., Lima, M.O., Higuchi, H. and Silveira, I.M. (2002), A Contribution to the Establishment of Reference Values for Total Mercury Levels in Hair and Fish in Amazonia, Environmental Research Section A, 90, 6-11.

Sexton, D., Powell, K., Liddle, J., Smrek, A. and Smith, J.C. (1978), A monoccupational outbreak of inorganic mercury vapor poisoning, Arch. Environ. Health., (July-August), 186-191.

Sherlock, J.C., Lindsay, D.G., Evans, W.H., Hislop, J.E. and Collier, T.R. (1982), Duplication diet study on mercury intake by fish consumers in the U.K., Arch. Environ. Health, 37, 271-278.

Shrader, D.E. and Hobbins, W.B. (1983), The determination of mercury by cold vapor atomic absorption. Varian Instruments at Work - Atomic Absorption, Number AA-32. 
Sikorski, R., Juszkiewicz, T. and Paszkowski, T. (1987), Women in dental surgeries: Reproductive hazards in occupational exposure to metallic mercury, Int. Arch. Occup. Environ. Health., 59, 551-557.

Sin, Y.M., Lim, Y.F. and Wong, M.K. (1983), Uptake and distribution of mercury in mice from ingesting soluble and insoluble mercury compounds, Bull. Environ. Contam Toxicol., 31, 605-612.

Skerfving, S. (1988), Mercury in women exposed to methyl mercury through fish consumption and in their newborn babies and breast milk, Bull. Environ. Contam. Toxicol., 41, 475-482.

Skog, E. and Wahlberg, J. (1964), A comparative investigation of the percuntaneous absorption of metal compounds in the guinea pig by means of the radioactive isotopes: ${ }^{51} \mathrm{Cr},{ }^{58} \mathrm{Co},{ }^{65} \mathrm{Zn},{ }^{110} \mathrm{Ag},{ }^{115} \mathrm{Cd},{ }^{203} \mathrm{Hg}, J$. Invest Dermatol., 43, 187-192

Smith, R.G., Vorwald, A.J., Patel, L.S. and Mooney, T.F.Jr. (1970), Effects of exposure to mercury in the manufacture of chlorine, Am. Ind. Hyg. Assoc. J., 31, 687-700.

Snodgrass, W., Sulivan, J. B., Rumack, B.H. and Hashimoto, C. (1981), Methyl mercury poisoning from home gold ore processing: Use of penicillamine and dimercaprol, J. Am. Med. Assoc., 246, 1929-1931.

Snyder, R. and Seelinger, D. (1976), Methyl mercury poisoning: Clinical follow-up and sensory nerve conduction studies, J. Neurol Neurosurg. Psychiat., 39, 701-704.

Sondreal, E.A., Benson, S.A. and Pavlish, J.H. (2000), Status of research on air quality: mercury, trace elements, and particulate matter, Fuel Processing Technology, 65-66, 5-19.

Soni, J.P., Singhania, R.U., Bansal, A. (1992), Acute mercury vapor poisoning, Indian Pediatr., 29, 365-368.

Soria, M.L., Sanz, P., Martinez, D., Lopez-Artiguez, M., Garrido, R., Grilo, A. and Repetto, M. (1992), Total mercury and methyl mercury in hair maternal and umbilical blood and placenta from women in the Seville area, Bull. Environ. Contam. Toxicol., 48, 494-501.

Stopford, W., Bundy, S.d., Goldwater, L.J. and Bittikofer, J.A. (1978), Microenvironmental exposure to mercury vapor, AM. Ind. Hyg. Assoc. J., 39, 378-384.

Stratis, I. and Zachariades, G. (1989), Methylation and toxicity of mercury and mercury compounds on human and on marine organisms, In: Proc. of the $1^{\text {st }}$ International Conference of Environmental Science and Technology, Ed. Prof. Th. Lekkas, Department of Environmental Studies, University of the Aegean, Molivos, Lesvos, Greece, Vol. B, pp. 74-83 (in greek).

Sugata, Y. and Clarkson, T.W. (1979), Exhalation of mercury: Further evidence for an oxidation-reduction cycle in mammalian tissues, Biochem. Pharmacol., 28, 3474-3476.

Sundberg, J and Oskarson, A. (1992), Placental and lactational transfer of mercury from rats exposed to methyl mercury in their diet: Speciation of mercury in the offspring, J. Trace Elem. Exp. Med., 5, 47-56.

Suzuki, T., Yonemoto, J., Satoh, H., Naganuma, A., Imura, N. and Kigama, T. (1984), Normal organic and inorganic mercury levels in the human feto-placental system, J. Appl. Toxicol., 4, 249-252.

Takahata, N., Hayashi, H., Watanabe, B. and Anso, T. (1970), Accumulation of mercury in the brains of two autopsy cases with chronic inorganic mercury poisoning, Folia. Psychiatr. Neurol. Jpn., 24, 59-69.

Tamashiro, H., Akagi, H. and Arakaki, M. (1984), Causes of death in Minamata disease: Analysis of death certificates, Int. Arch. Occup. Environ. Health., 54, 135-146.

Tamashiro, H., Arakaki, M., Futatsuka, M. and Lee, E.S. (1986), Methylmercury exposure and mortality in southern Japan: A close look at causes of death, J. Epidemiol. Commun. Health, 40, 181-185

Teisinger, J. and Fiserova - Bergova, V. (1965), Pulmonary retention and excretion of mercury vapors in man, Ind. Med. Surg., 34, 580.

Thomas, D., Fischer, H., Sumler, M., Marcus, A.H., Mushak, P. and Hall, L.L. (1987), Sexual differences in the excretion of organic and inorganic mercury by methyl mercury treated rats, Environ. Res., 43, 203-216.

Troen, P., Kaufman, S.A. and Katz, K.H. (1951), Mercuric bichloride poisoning, N. Engl. J. Med., 244, 459-463.

Tsuji, J.S. and Robinson, S. (2002), Separating potential source exposure from background exposure in subsistence populations in developing countries, Toxicology, 181-182, 467-470.

UNEP/FAO/WHO (1987), Assessment of the state of pollution of the Mediterranean Sea by Mercury and Mercury compounds, MAP Technical Reports Series No.18, UNEP, Athens.

US EPA (1992b), Arsenic and mercury, In: Workshop on removal, recovery, treatment, and disposal, Abstract Proceedings, Alexandria, Virginia, August 17-20, EPA/600/R-92/105.

US EPA (1997a), The National Survey of Mercury Concentrations in Fish, Database Summary, 1990-1995. September 29, 1997. 
US EPA (1997b), Mercury study, report to congress, Volume II: An Inventory of Anthropogenic Mercury Emissions in the United States, Office of Air Quality Planning \& Standards and Office of Research and Development.

US EPA (1997c), Mercury study, report to congress, Volume V: Health Effects of Mercury and Mercury Compounds, Office of Air Quality Planning \& Standards and Office of Research and Development.

Vahter, M., Akesson, A., Lind, B., Bjors, U., Schutz, A. and Berglund, M. (2000), Longitudinal Study of Methylmercury and Inorganic Mercury in Blood and Urine of Pregnant and Lactating Women, as Well as in Umbilical Cord Blood, Environmental Research, Section A, 84, 186-194.

Vahter, M., Berglund, M., Akesson, A. and Liden, C. (2002), Metals and Women's Health, Environmental Research, Section A, 88, 145-155.

Verbeck, M., Salle, H. and Kemper, C. (1986), Tremor in workers with low exposure to metallic mercury, Am. Ind. Hyg. Assoc. J., 47, 559-562.

Verschaeve, L., Kirsch-Volders, M., Susanne, C., Groetenbriel, C., Haustermans, R., Lecomte, A. and Roossels, D. (1976), Genetic damage induced by occupationally low mercury exposure, Environ. Res., 12, 306-316.

Von Burg, R. and Rustam, H. (1974b), Conduction velocities in methyl mercury poisoned patients, Bull. Environ. Contam. Toxicol., 12, 81-85.

Von Burg, R. and Rustam, H. (1974a), Electrophysiological investigations of methyl mercury intoxication in humans: Evaluation of peripheral nerve by conduction velocity and electromyography, Electroenceph. Clin Neurophysiol., 37, 381-392.

Vroom, F.Q. and Greer, M. (1972), Mercury vapor intoxication, Brain, 95, 305-318.

Watanabe, K.H., Desimone, F.W., Thiyagarajah, A., Hartley, W.R. and Hindrichs, A.E. (2003), Fish tissue quality in the lower Mississippi River and health risks from fish consumption, The Science of the Total Environment, 302, 109-126.

Welsh, S.O. (1979), The protective effect of vitamine E and N, n-diphenyl-p-phenylenediamine against methyl mercury toxicity in the rat, J. Nutr., 109, 1673-1681.

WHO (World Health Organization), (1976), Environmental Health Criteria 121 Geneva, Switzerland.

WHO (World Health Organization), (1989), Mercury - environmental aspects, Environmental Health Criteria 86, Geneva.

WHO (World Health Organization), (1990), Methylmercury, Environmental Health Criteria 101, Geneva.

WHO (World Health Organization), (1990), Inorganic mercury. Vol. 101, World Health Organization International Programme on Chemical Safety, Geneva, Switzerland, 168.

Yoshida, M., Satoh, H. and Kishimoto, T. (1992), Exposure to mercury via breast milk in suckling offspring of maternal guinea pigs exposed to mercury vapor after parturition, J. Toxicol. Environ. Health, 35, 135139.

Zalups, R.K. and Cherian, M.G. (1992), Renal metalloothionein metabolism after a reduction of renal mass: II. Effects of zinc pre-treatment on the renal toxicity and intrarenal accumulation of inorganic mercury, Toxicology, 71, 103-117. 